\title{
Evaluation of Topical Application of Vajradanti Gel in Prevention of Gingivitis
}

\author{
Anjani Kumar Pathak1, Vibha Singh ${ }^{2 *}$, Mahesh Pal ${ }^{3}$, Tripti Mishra ${ }^{3}$, Kopal Goel ${ }^{4}$, \\ Vaibhav Sheel Gupta ${ }^{4}$
}

\author{
${ }^{1}$ Department of Periodontology, Faculty of Dental Sciences, King George's Medical University, Lucknow, India \\ ${ }^{2}$ Department of Oral and Maxillofacial Surgery, Faculty of Dental Sciences, King George’s Medical University, Lucknow, India \\ ${ }^{3}$ Phytochemistry Division, CSIR-National Botanical Research Institute, Lucknow, India \\ ${ }^{4}$ Department of Prosthodontics, Faculty of Dental Sciences, King George’s Medical University, Lucknow, India \\ Email: dr.anjanipathak@gmail.com, ^vibhasinghraghuvanshi@gmail.com, vaibhavsheelgupta@gmail.com
}

How to cite this paper: Pathak, A.K., Singh, V., Pal, M., Mishra, T., Goel, K. and Gupta, V.S. (2017) Evaluation of Topical Application of Vajradanti Gel in Prevention of Gingivitis. Open Journal of Stomatology, 7, 105-112.

https://doi.org/10.4236/ojst.2017.72006

Received: October 15, 2016

Accepted: February 6, 2017

Published: February 9, 2017

Copyright (c) 2017 by authors and Scientific Research Publishing Inc. This work is licensed under the Creative Commons Attribution International License (CC BY 4.0).

http://creativecommons.org/licenses/by/4.0/

\begin{abstract}
Vajradanti means strong teeth in Hindi. The medicinal properties of Vajradanti plant are well reported in Ayurveda. Its botanical name is Barleria prionitis $\mathrm{L}$. and it belongs to family Acanthaecae. The use of herbal products in the field of medicine has gained popularity in recent years. In India, herbal plants are used as a regular source of medicine. Plants, such as Turmeric, Ashoka and Triphala, are some common household names being widely used nowadays. One such name is Barleria prionitis L. or Vajradanti, having antiarthritic, anti-inflammatory and anti-fertility properties. The leaves of this flower are also believed to provide relief in tooth ache. So these properties lead us to the use of this shrub in the remedy of dental diseases. Materials and Methods: The study was conducted in the Department of Periodontology, in collaboration with the Department of Oral and Maxillofacial Surgery, Faculty of Dental Sciences, King George's Medical University, Lucknow, India and N.B.R.I. Lucknow. A total of 80 subjects, from age group 20 - 50 years, were selected. The study unit consisted of patients of chronic gingivitis. Simple random sampling, utilizing computer generated random numbers, was employed to assign the participants to two groups, "I" and "II", each having 40 participants. In patients of Group-I scaling and root planing was performed, whereas in patients of Group-II, scaling and root planing was performed and subjects were advised to apply Vajradanti gel twice daily after brushing. Statistical Analysis: Data were summarized as mean \pm SD. Pre and post outcome results of two groups were compared by the paired t-test. Conclusions: Based on the observations and results of our study, it can be concluded that scaling and root planing remains the gold standard for the treatment of gingival and periodontal diseases while the Vajradanti gel (Barleria prionitis L.) can be effectively used as an adjunct to mechanical plaque control in prevention of
\end{abstract}


chronic gingivitis. The beneficial effect of Vajradanti can be attributed to its anti inflammatory properties.

\section{Keywords}

Vajradanti, Chronic Gingivitis, Barleria prionitis L., Bio Film, Plaque

\section{Introduction}

In India, herbal plants such as Vajradanti and Turmeric are used as a regular source of medicine. In traditional system of Indian medicine, Vajradanti is known as Sahachara, Baana or Kurantaka. The medicinal properties of Vajradanti are well reported in Ayurveda. The Leaves of Vajradanti are used for treating bleeding gums and tooth ache. It belongs to family "Acanthaecae" and occurs in hotter part of India, Sri Lanka and tropical Asia [1].

Gingivitis and periodontitis are plaque-associated infections initiated by the accumulation and maturation of pathogenic bio-film on the surfaces of teeth and oral mucosa. These microbial bio-films are complex communities of bacteria and are common in the human body and in the environment. In recent years dental plaque has been identified as a bio-film. The structure, microbiology and patho-physiology of dental bio-films have been well studied. The structure of the bio-film enhances the component organism's resistance to both the host defence system and antimicrobials. If not removed regularly, the bio-film undergoes maturation and results in the formation of a pathogenic bacteria complex which can lead to dental caries, gingivitis, and periodontitis. In addition, dental biofilms especially sub-gingival plaque in the patient with periodontitis has been associated with various systemic disease and disorders including cardiovascular disease, diabetes mellitus, respiratory disease and adverse pregnancy outcomes.

A majority of the world's population is affected by these diseases. The severity of the disease is directly related to the plaque levels and varies from person to person. Hence meticulous oral hygiene can restore gingival health [1] [2] [3] [4]. The focus of any attempt to prevent and control periodontal disease is the maintenance of an effective level of plaque control by the individual.

Plaque control can be achieved either by mechanical or chemical means. Mechanical means include brushing, flossing, use of interdental cleansing aids, and oral prophylaxis. These methods are time-consuming and their effectiveness depends upon individual dexterity. The use of chemicals in plaque control is always an adjunct to mechanical methods [4]. The various agents of chemical plaque control come in various forms such as mouth rinses, sprays, irrigators, gels, chewing gums and many more.

Vajradanti is an annual shrub $1-3$ feet in height and its leaves are chewed to relieve tooth ache and parts of the root are applied to treat glandular swellings and disperse boils. It also has been reported as an anti-arthritic, anti-inflammatory and anti-fertility agent. It is used in stiffness of limbs, enlargement of the 
scrotum and in sciatica. The leaves of this plant are used to provide healing of wounds, to relieve joint pain and bleeding gums. Because of its anti-odontalgic properties, it is also known as Vajradanti (meaning strong teeth in Hindi) [5] [6].

It has been seen that the crude extract of Barleria prionitis L. possesses good activity against dental caries, due to its wide range of medicinal properties. It is important to study the role of Vajradanti in the prevention of gingivitis. The purest gel form of this shrub was used in this study and it was directly applied on the gingival tissues.

\section{Materials and Methods}

The study was conducted in the Department of Periodontology, in collaboration with the Department of Oral and Maxillofacial Surgery, Faculty of Dental Sciences, King George's Medical University, Lucknow, India and National Botanical Research Institute, Lucknow. The study unit consisted of patients of chronic gingivitis. Sample size was calculated by discussing with a stastician. Total of 80 subjects of both the sexes from age group 20 to 50 years who met the following inclusion criteria were included: 1) Patients suffering from mild, moderate or severe gingivitis. 2) Subjects having all the teeth erupted (excluding third molars). Exclusion criteria were: 1) Pregnant and lactating females. 2) History of any systemic disease. 3) Smokers.

Ethical clearance was obtained from the Ethical Committee, King George's Medical University, Lucknow. A written consent was taken from all the participants. Before initiating the study each patient was informed about the purpose and design of the study

The participants were assigned into two groups "I" and "II" each group comprised of 40 participants by Simple random sampling method (computer generated random numbers were used). In Group I subjects scaling and root planning was performed as a part of the treatment. In Group II subjects scaling and root planning was performed and the subjects were advised to use an experimental gel (Vajradanti gel) twice daily after brushing.

The following parameters i.e. gingival index (GI) by Loe and Silness, plaque index (PI) by Silness and Loe and probing pocket depth (PPD) were recorded. Recording of indices was done at 0,4 , and 12 weeks; and all the records were maintained on a case history proforma.

The clinical data were compiled and was subjected to statistical analysis.

Statistical analysis: The recorded data was summarized as mean \pm standard deviation (SD). The group differences were compared by using Independent samples " $\mathrm{t}$ "-test and the significance of difference within group was compared using paired " $\mathrm{t}$ "-test. " $\mathrm{P}$ " value of less than 0.05 was considered to be statistically significant. Data analysis was done using Statistical Package for Social Sciences version 15.0.

\subsection{Vajradanti Gel Preparation}

The whole aerial part of the Barleria prionitis L., was collected during June 2014 
from Lucknow, Uttar Pradesh India. The samples were authenticated by the plant taxonomists at CSIR-National Botanical Research Institute, Lucknow, India.

\subsection{Extraction}

The collected plant material Barleria prionitis L., were shade dried and milled into powder $(60 \mathrm{~g})$ then sieved through a 40 -mesh sieve and extracted with ethanol $(1000 \mathrm{~mL} \times 4$ times $)$ in an extractor for $36 \mathrm{~h}$ by maceration. The extract was filtered through Whatman filter paper and evaporated to dryness using rotatory evaporator (Buchi Rotavapor-R2, Flawil, Switzerland) under reduced pressure at $45^{\circ} \mathrm{C}$. Dried residues were stored in vials at $4^{\circ} \mathrm{C}$ in the refrigerator for further use.

\subsection{Dose Preparation}

Ethanolic extract of Barleria prionitis was used for dose preparation along with glycerine as a carrier. Three doses were prepared along with carrier in different ratio and coded as BP-1 (1:3), BP-2 (1:1) and BP-3 (3:1). In the assay glycerine was used as vehicle control. After pilot study BP-3(3:1) was used in the present study.

\section{Results}

A total of 80 subjects of both the sexes (male $=44$ and female $=36$ ) from age group 20 to 50 years with mainly low and medium socio-economic status were included in the study (Table 1). The participants were assigned into two groups "I" and "II" of 40 participants each. In Group I subjects scaling and root planning was performed as a part of the treatment. In Group II subjects scaling and root planning was performed and the subjects were advised to use an experimental gel (Vajradanti gel) twice daily after brushing. The following parameters i.e. gingival index (GI) by Loe and Silness, plaque index (PI) by Silness and Loe and probing pocket depth (PPD) were recorded. Recording of indices was done at 0,4 , and 12 weeks; and all the records were maintained on a case history proforma.

\section{Plaque Index (PI)}

The pre-(baseline) and post-(after 4 weeks and after 12 weeks) PI of two groups are summarized in Table 2. The mean PI in both groups decreased after the treatment, and the decrease was more evident in Group II than in Group I.

On comparing the mean PI within the groups, the PI in Group I (SRP) decreased significantly after 4 th and 12th week, as compared to baseline. However, the mean PI did not decrease significantly $(\mathrm{p}>0.05)$ after 12 weeks as compared to 4 weeks. Similarly, in Group B (SRP+ VAJRADANTI GEL), the PI decreased significantly after 4 th and 12th week, as compared to baseline. However, like Group I mean PI in group II did not decrease significantly ( $p>0.05)$ after 12 weeks as compared to 4 weeks.

Further, comparing the mean PI between the groups, the PI did not differ ( $\mathrm{p}>$ 
0.05) between the two groups at baseline indicating that PI was comparable. However, after 4th and 12th week, the mean PI in group-II decreased significantly ( $\mathrm{p}<0.001)$, as compared to the SRP group alone.

\section{Gingival Index (GI)}

The pre-intervention (baseline) and post-intervention (after 4 weeks and after 12 weeks) GI of two groups are summarized in Table 3. The mean GI in both groups decreased after the treatment, and the decrease was more evident in Group II than Group I.

On comparing the mean GI within the groups, the GI in Group I (SRP) decreased significantly after 4 th and 12th week, as compared to baseline. Similarly, in Group B (SRP + VAJRADANTI GEL), the GI decreased significantly after 4th

Table 1. socio-demographic data of subjects.

\begin{tabular}{ccc}
\hline $\begin{array}{c}\text { Gender } \\
(\text { Total }=80)\end{array}$ & Male & 44 \\
Fge Group & $20-30$ years & 36 \\
\hline$(20-50$ years $)$ & $30-40$ years & 22 \\
& $40-50$ years & 40 \\
Socioeconomic Status & Low & 18 \\
\hline & Medium & 45 \\
& High & 30 \\
\hline
\end{tabular}

Table 2. Pre and Post PI (mean \pm SD) of two groups.

\begin{tabular}{ccccccc}
\hline & \multicolumn{2}{c}{ Group I } & \multicolumn{2}{c}{ Group II } & \multicolumn{2}{c}{$\begin{array}{c}\text { Statistical Significance (Group I vs. } \\
\text { Group II) (Independent samples “t”-test) }\end{array}$} \\
\hline & Mean & SD & Mean & SD & $\mathrm{t}^{\text {' }}$ & p' \\
\hline Base line & $2.19^{\mathrm{b}, \mathrm{c}}$ & 0.49 & $2.22^{\mathrm{b}, \mathrm{c}}$ & 0.48 & -0.315 & 0.754 \\
4 weeks & $1.17^{\mathrm{a}, \mathrm{c}}$ & 0.27 & $0.99^{\mathrm{a}, \mathrm{c}}$ & 0.20 & 3.730 & $<0.001$ \\
12 weeks & $1.06^{\mathrm{a}, \mathrm{c}}$ & 0.22 & $0.69^{\mathrm{a}, \mathrm{c}}$ & 0.19 & 8.803 & $<0.001$ \\
\hline
\end{tabular}

Figures in superscript show within group differences (Paired t-test). $a=$ Significant as compared to baseline, $\mathrm{b}=$ Significant as compared to 4 weeks, $\mathrm{c}=$ Significant as compared to 12 weeks; for all between group comparisons $\mathrm{p}<0.001$.

Table 3. Pre and Post GI (mean \pm SD) of two groups.

\begin{tabular}{ccccccc}
\hline & \multicolumn{2}{c}{ Group I } & Group II & \multicolumn{2}{c}{$\begin{array}{c}\text { Statistical Significance (Group I vs. } \\
\text { Group II) (Independent samples “t”-test) }\end{array}$} \\
\hline & Mean & SD & Mean & SD & $\mathrm{t}^{\prime}$ & p' \\
\hline Base line & $2.22^{\mathrm{b}, \mathrm{c}}$ & 0.43 & $2.29^{\mathrm{b}, \mathrm{c}}$ & 0.48 & -0.795 & 0.429 \\
4 weeks & $1.21^{\mathrm{a}, \mathrm{c}}$ & 0.26 & $0.99^{\mathrm{a}, \mathrm{c}}$ & 0.21 & 4.488 & $<0.001$ \\
12 weeks & $1.09^{\mathrm{a}, \mathrm{c}}$ & 0.21 & $0.67^{\mathrm{a}, \mathrm{c}}$ & 0.20 & 10.182 & $<0.001$ \\
\hline
\end{tabular}

Figures in superscript show within group differences (Paired t-test). a = Significant as compared to baseline, $\mathrm{b}=$ Significant as compared to 4 weeks, $\mathrm{c}=$ Significant as compared to 12 weeks; for all between group comparisons $\mathrm{p}<0.001$. 
and 12th week, as compared to baseline. However, mean PI in group II did not decrease significantly ( $p>0.05$ ) after 12 weeks as compared to 4 weeks. Further, comparing the mean GI between the groups, the GI did not differ significantly ( $p>0.05$ ) between the two groups at baseline indicating that GI was comparable. However, after 4 th and 12th week, the mean GI in group II decrease significantly $(\mathrm{p}<0.001)$, as compared to the SRP group alone.

\section{Probing Pocket Depth (PPD)}

The pre-(baseline) and post-(after 4 weeks and after 12 weeks) PPD of two groups are summarized in Table 4. The mean PPD in both groups decrease after the treatment, and the decrease was evident higher in Group II than Group I.

On comparing the mean PPD within the groups, the PPD in Group I (SRP) decrease significantly after 4 th and 12th week, as compared to baseline. However, the mean PPD did not decrease significantly ( $p>0.05)$ after 12 weeks as compared to 4 weeks. Similarly, in Group B (SRP+ VAJRADANTI GEL), the PPD decreases significantly after 4 th and 12th week as compared to baseline. However, like Group I mean PPD in group II did not decrease significantly ( $\mathrm{p}>$ 0.05) after 12 weeks as compared to 4 weeks. Further, comparing the mean PPD between the groups, the PI did not differ $(p>0.05)$ between the two groups at baseline indicating that PI was comparable. However, after 4th and 12th week, the mean PI in group II decreases significantly $(\mathrm{p}<0.001)$ as compared to the SRP group alone.

\section{Discussion}

Today, herbal products symbolize safety in contrast to synthetic products that are regarded as unsafe to humans and the environment. These evidences contribute to support and quantify the importance of screening natural plants. Herbs like Neem, Turmeric, Aloe Vera and clove are frequently used in dentistry. Barleria prionitis L. Family Acanthaecae; is an annual shrub, 1 - 3 feet high, found throughout Africa, India, Sri Lanka and tropical Asia. The medicinal properties of Vajradanti are well reported in Ayurveda as anti-inflammatory and diuretic. Traditionally leaves are used for treating bleeding gums and tooth ache. It has a long history of healing and curative properties.

In our study, the anti-inflammatory action of Vajradanti was evaluated on

Table 4. Pre and Post PPD (mean \pm SD) of two groups.

\begin{tabular}{ccccccc}
\hline & \multicolumn{2}{c}{ Group I } & \multicolumn{2}{c}{ Group II } & \multicolumn{2}{c}{$\begin{array}{c}\text { Statistical Significance (Group I vs. } \\
\text { Group II) (Independent samples “t”-test) }\end{array}$} \\
\hline & Mean & SD & Mean & SD & t' & p' \\
\hline Base line & $4.06^{\mathrm{b}, \mathrm{c}}$ & 0.71 & $3.83^{\mathrm{b}, \mathrm{c}}$ & 0.72 & 1.611 & 0.110 \\
4 weeks & $3.54^{\mathrm{a}, \mathrm{c}}$ & 0.56 & $3.02^{\mathrm{a}, \mathrm{c}}$ & 0.50 & 4.880 & $<0.001$ \\
12 weeks & $3.39^{\mathrm{a}, \mathrm{c}}$ & 0.46 & $2.34^{\mathrm{a}, \mathrm{c}}$ & 0.43 & 11.864 & $<0.001$ \\
\hline
\end{tabular}

Figures in superscript show within group differences (Paired t-test). $\mathrm{a}=$ Significant as compared to baseline, $\mathrm{b}=$ Significant as compared to 4 weeks, $\mathrm{c}=$ Significant as compared to 12 weeks; for all between group comparisons $\mathrm{p}<0.001$. 
clinical parameters using the PI, GI, and PPD, which showed a significant reduction. The mean PI, GI and PPD in both the groups decrease after the treatment, and the decrease was more evident in Group II (Vajradanti) than Group I. Similar studies have been done previously with herbs like turmeric where the authors have evaluated the effect of turmeric on clinical parameters using the PI, GI, and PPD and found that turmeric gel can be effectively used as an adjunct to mechanical plaque control in the prevention of plaque and gingivitis [7].

Barleria prionitis L. or Vajradanti is supposed to have adjunctive role in the prevention of gingival diseases. The results proved that Barleria prionitis along with SRP leads to reduction in plaque formation, gingival bleeding and pocket depth.

The possible mechanism of action of Vajradanti as an anti-bacterial agent could be due to tannins, saponins, phenolic compounds, essential oils and flavonoids present in them [6]. The antimicrobial potency of Barleria prionitis may be due to presence of five iridoidglucoside esters, acetyl barlerin 6, 8, di-o-acetyl shanzhisisde methyl ester, shanzhiside methyl ester verbascoide [6] [8]. It has been seen that crude extract of Barleria prionitis possess good activity against dental caries-causing oral pathogens where modern therapy has failed. The crude extract of the plant also showed antibacterial activity against Staphylococcus aureus and Pseudomonas aeruginosa in initial anti-bacterial screening [9]. It has been found that the extract of Barleria prionitis can damage E. coli cell membrane by exerting profound physiological changes that lead to bacterial death [10]. Crude methanolic extract of Barleria prionitis revealed in vitro antioxidant, total phenol and flavonoid contents, anti-inflammatory and anti-microbial potential. A wide range of phytochemical constituents including balarenone, pipataline, prionisides, barlerinoside, verbascoside, shanzhisde, methyl ester, barlerin, pipataline, acety lbarlerin, lupulinoside, scutellarein have been isolated from different parts of the plant [2] [3]. Extracts and phytochemicals isolated from the plant have been found to possess wide range of pharmacological activities without any side effects [6]. The herbal mouthwash, made from crude extract of Barleria prionitis was effective in management of gingivitis as reported in the literature.

Crude extract obtained from bark of the Barleria prionitis was found to be effective against dental caries causing pathogens even better than modern antibiotic therapy. It also has antifungal properties against Candida albicans and Saccharomyces cerevisiae. A study confirmed antimicrobial potential of Barleria prionitis L. Against oral microbial flora for improvement of oral hygiene and this was also supporting its folklore application as preventive remedy against oral microbial disease.

\section{Conclusion}

Based on the results and observations of our study, it can be concluded that Vajradanti can be used as an adjunct to mechanical plaque control in the prevention of plaque and gingivitis. It is a plant of miraculous nature which can be used 
in prevention of dental diseases without any side effects. It has its traditional use and is well documented to use in modern medicine too. However to recommend the use of Vajradanti, it is required to carry out a long-term study on a large sample to evaluate its efficacy as an anti-plaque, anti-inflammatory agent, and other properties.

\section{Limitations of the Study}

A larger sample size and longer follow up are required for more conclusive results.

\section{References}

[1] Yadav, R., Yadav, S.K., et al. (2013) Dental Diseases and Its Cure. Asian Journal of Pharmaceutical and Clinical Research, 6, 16-20.

[2] Fine, D.H. (1995) Chemical Agents to Prevent and Regulate Plaque Development. Periodontology 2000, 8, 87-107.

[3] Van der Weijden, F. and Slot, D.E. (2011) Oral Hygiene in the Prevention of Periodontal Diseases: The Evidence. Periodontology 2000, 55, 104-123. https://doi.org/10.1111/j.1600-0757.2009.00337.x

[4] Lindhe, J. (2008) Text Book of Clinical Periodontology and Implant Dentistry. 5th Edition, Wiley Blackwell, UK, 748-754.

[5] Pachori, R., Kulkarni, N.S., Bodhankar, M.G. and Aithal, S.C. (2016) Antimicrobial Studies of Herbs and Shrubs against Dental Pathogens. Journal of Empirical Biology, 1, 10-16.

[6] Diwan, P.D. and Gadhikar, Y.A. (2012) Assessment of Phytochemical Composition and Antibacterial Activity of Different Extracts of Barleria prionitis Leaves against Oral Micro Flora to Improve Dentalhygiene. Asian Journal of Pharmaceutical and Clinical Research, 5, 182-184.

[7] Singh, V., Pathak, A., Sareen, S. and Goel, K. (2015) Comparative Evaluation of Topical Application of Curcumin and 0.2\% Chlorhexidine Gluconate in Prevention of Gingivitis. National Journal of Maxillofacial Surgery, 6, 67-71. https://doi.org/10.4103/0975-5950.168238

[8] Banerjee, D., Maji, A.K., Mahapatra, S. and Banerji, P. (2012) Barleria prionitis Linn. A Review of Its Traditional Use, Phytochemistry, Pharmacology and Toxicity. Research Journal of Phytochemistry, 6, 31-41.

[9] Aneja, K., Joshi, R. and Sharma, C. (2010) Potency of Barleria prionitis L Bark Extract against Oral Disease Causing Strains of Bacteria and Fungi of Clinical Origin. New York Science Journal, 3, 5-12.

[10] Shukla, P., Singh, A., Gwari, S., et al. (2011) In Vitro Propagation of Barleria prionitis and Its Antibacterial Activity. International Journal of Pharma Professional Research, 2, 170-172. 
Submit or recommend next manuscript to SCIRP and we will provide best service for you:

Accepting pre-submission inquiries through Email, Facebook, LinkedIn, Twitter, etc. A wide selection of journals (inclusive of 9 subjects, more than 200 journals)

Providing 24-hour high-quality service

User-friendly online submission system

Fair and swift peer-review system

Efficient typesetting and proofreading procedure

Display of the result of downloads and visits, as well as the number of cited articles Maximum dissemination of your research work

Submit your manuscript at: http://papersubmission.scirp.org/

Or contact ojst@scirp.org 